\title{
SPECIES INTERACTIONS AND SUBSTRATE PREFERENCES IN THREE SMALL BENTHIC FISHES
}

\author{
J. Prenda', S. Rossomanno' and P. D. Armitage' \\ 1. Departamento de Ciencias Agroforestales, Facultad de Ciencias Experimcntalcs, Universidad de Huclva, Campus de La Rábida, \\ 21819 Palos dc la Frontera, Huelva, Spain. E-mail: jprenda@uhu.es \\ 2. Quercianclla, via dei Ginepri 25, 57015 Livorno, Italy \\ 3. Institute of Freshwater Ecology, River Laboratory, East Stoke, Wareham, Dorset BH20 6BB, UK.
}

Keywords: microhabitat preferences, stream fish, biotic interactions, benthos, UK.

Palabras clave: preferencias de microhábitat, peces fluviales, interacciones bióticas, bentos, Reino Unido.

\begin{abstract}
The interactions between bullhead (Cottus gobio), stone loach (Barbatula barbatula) and gudgeon (Gobio gobio) and subsequently their influence on the exclusion capacity of these species were examined in laboratory experiments. When a combination of gravel, sand and sand plus shelters substrate types were offered, the three species selected sheltered substrates. This preference was stronger when the three species were together rather than when in allopatry. None of the species showed any preference to coexist with another under sheltered positions. When only one specics occupied a sheltered position it was alone, without any other conspecific. Dispersal patterns differed bctween species but during this process there was no evidence of any species association. This study highlights a very limited interspecific interaction between bullhead, stone loach and gudgeon, and shows that intraspecific exclusion in these species was much more important than the interspecific one.
\end{abstract}

\section{INTRODUCTION}

Little is known about the competitive interactions bctween fishes and their effect on their distribution patterns in European rivers. However, the spatial segregation between species of similar size and habits has been long reported, both in the field and experimentally (SMYLY, 1957; WELTON et al., 1983; GREENBERG, 1988; MANN, 1989; ZWEIMÜLLER, 1995). This applies especially to the interactions and habitat preferences of bullhead (Cottus gobio), stone loach (Barbatula barbatula) and gudgeon (Gobio gobio), three small benthic species that coexist throughout Europe.

SMYLY (1957) observed a mutual avoidance and negative correlation bctween bullhead and stone loach in some streams in the Lake District Area. Similarly, MANN (1989) noted a large increase in stone loach abundance when bullhead density diminished in a chalk stream. WELTON et al. $(1983,1991)$ observed, both under natural conditions and experimentally, that bullhead and stone loach coexisted through habitat partitioning in the River Frome. A similar conclusion was reached by ZWEIMÜLLER (1995) for stone loach and gudgeon in an

Limnetica, 13 (1): 47-53 (1997)

(1) Asociación Espanola de Limnología, Madrid. Spain
Austrian stream. PRENDA et al. (1997) found that the three species tended to select different microhabitats. However this segregation was not strong enough to produce any negative correlation in their distribution patterns and the three species extensively overlapped in microhabitat use (PRENDA et al. 1997).

In this paper we consider the potential interactions between bullhead, stone Ioach and gudgeon, and subsequently examine their influence on the exclusion capacity of these species, both intraspecifically and interspecifically. This was tested in laboratory experiments on dispersal patterns, shifts in substrate preferences by species in single versus mixed specics groups and interactive segregation under sheltered positions.

\section{MATERIALS AND METHODS}

The fish were captured by electrofishing in the Mill Stream, a side channel of the River Frome (Dorset, UK) (Nat. Grid. Ref. SY 872870). Fish werc held for two days in a 1001 flowthrough stock tank until they werc needed for experiments. In each experiment different fish were employed. 


\section{Experimental design}

Two different sets of experiments were carried out to test for substrate preferences and species associations, respectively. All these experiments were carried out in the absence of prey organisms to avoid the effect of non-random distribution of prey.

The experiments were conducted in an aquarium $(270 \mathrm{~cm} x$ $49 \mathrm{~cm} \times 35 \mathrm{~cm}$ ), containing 4001 of water through which a continuous flow of river water was maintained $\left(0.085 \mathrm{ls} \mathrm{s}^{1}\right)$. The experiments were carried out inside a large room with daylight. Water temperature was in the range $17-21^{\circ} \mathrm{C}$.

The aquarium was separated into three compartments of approximately $90 \mathrm{~cm}$ long, using wood partitions, and was set up under two different conditions. The fish could not move between compartments.

i) Four separate experiments were performed to analyse the substrate preferences of each species, and how the presence of the other two species affected these preferences. In the sympatric trial (the three species together) and in the three allopatric ones (each species separately) the bottom area of each compartment was divided into three equal parts, each containing a different substratum: sand $(<1 \mathrm{~mm})$, gravel $(10-20 \mathrm{~mm})$ and sand on which five artificial shelters were placed. The artificial shelters were made of perforated PVC pipe cut longitudinally $(5 \mathrm{~cm}$ radius, $15 \mathrm{~cm}$ length, $25 \times 1 \mathrm{~cm}$ diameter holes per shelter). Each compartment presented a random combination of the three substrata types to avoid the cage effect.

In the allopatric experiments between four and six individuals of a similar size (Table I) were added to each compartment. In the sympatric experiment, two of each species were placed in each compartment (Table I). The density of fish was similar to mean density found under natural conditions (PRENDA et al., 1997).

On each occasion the number of individuals of each fish species found per substratum type in each compartment was recorded. The fish locations were quickly noted from a platform placed approximately $1 \mathrm{~m}$ above the aquarium. All the observations were carried out between 9:00 am and 16:00 pm over two consecutive days. Fish locations were noted between 6 and 14 times in each hour (Table I).

To test for substratum preferences under both allopatric and sympatric conditions, we compared the mean number of individuals of each fish species found per substratum type in

TABLE I. Mean total length and mean total weight of fish per compartment used in the experiments carried out to test substrate preferences. The number of time each species was scored in each experiment appears in the last column $(\mathrm{N}) . \mathbf{C l}, \mathbf{C 2}$ and $\mathrm{C} 3$ : compartments $\mathbf{1}$ to $\mathbf{3}$, respectively.

TABLA I. Longitud media total y peso fresco total medio de los ejemplares utilizados en cada compartimento para testificar las preferencias de substrato. El número de veces que cada especie fue contabilizada en cada experimento se recoge en la última columna (N). C1, C2 y C3: compartimentos 1 a 3, respectivamente.

\begin{tabular}{|c|c|c|c|c|c|c|c|c|c|c|}
\hline \multirow[t]{2}{*}{ trial/specie } & \multicolumn{3}{|c|}{ C1 } & \multicolumn{3}{|c|}{$\mathrm{C} 2$} & \multicolumn{3}{|c|}{ C3 } & \multirow[t]{2}{*}{$\mathbf{N}$} \\
\hline & TL $\pm 1 \mathrm{SE}$ & $\mathrm{TW} \pm \mathbf{I} \mathrm{SE}$ & n & $\mathrm{TL} \pm 1 \mathrm{SE}$ & $\mathrm{TW} \pm 1 \mathrm{SE}$ & n & TL $\pm \mathbf{I ~ S E}$ & $\mathrm{TW} \pm 1 \mathrm{SE}$ & n & \\
\hline \multicolumn{11}{|l|}{ Allopatric } \\
\hline bullhead & $61.5 \mathrm{k} 1.5$ & $2.95 \mathrm{k} 0.41$ & 2 & $57.5 \mathrm{k} 2.5$ & $2.40 \pm 0.13$ & 2 & $60.5 \mathrm{k} 0.5$ & $2.61 \mathrm{k} 0.06$ & 2 & 12 \\
\hline stone loach & $67.5 \mathrm{k} 0.5$ & $2.98 \mathrm{k} 0.07$ & 2 & $67.5 \mathrm{k} 2.5$ & $2.95 \mathrm{k} 0.38$ & 2 & $63.0 \pm 0.0$ & $2.34 \mathrm{f} 0.01$ & 2 & 12 \\
\hline gudgeon & $135 \mathrm{k} 8.0$ & $19 \pm 2.7$ & 2 & $114 \mathrm{k} 14.0$ & $13.7 \pm 5.1$ & 2 & $107.5 \mathrm{k} 7.5$ & $11.3 \pm 2.6$ & 2 & 12 \\
\hline
\end{tabular}

\section{Sympatric}

\begin{tabular}{lcccccccccc} 
bullhead & $57.0 \pm 1.6$ & $2.17 \mathrm{k} 0.27$ & 6 & $56 \pm 1.9$ & $2.17 \mathrm{k} 0.22$ & 6 & $57.2 \mathrm{k} 2.0$ & $2.27 \mathrm{f} 0.30$ & 6 & 14 \\
Stone loach & $66.3 \pm 1.7$ & $2.61 \mathrm{k} 0.14$ & 6 & $62.2 \mathrm{k} 1.7$ & $2.14 \mathrm{k} 0.14$ & 6 & $65.8 \mathrm{k} 1.7$ & $2.59 \pm 0.20$ & 6 & 8 \\
gudgeon & $87.0 \mathrm{k} 13.2$ & $7.66 \mathrm{k} 2.69$ & 4 & $88.7 \mathrm{k} 21.7$ & $9.34 \mathrm{k} 5.95$ & 3 & $101.3 \mathrm{k} 18.5$ & $10.49 \mathrm{k} 4.55$ & 3 & 6 \\
\hline
\end{tabular}


each compartment with one-way ANOVA. When there existed significant differences between treatments (substrate type utilisation) the Tukey multiple range test was applied to establish homogeneous groups.

ii) To test the preferences displayed by each species to stay alone or to coexist with each other, we compared the mean frequency of appearance of all the possible species combinations per species observed under sheltered positions in experiment i) with one-way ANOVA. Here the treatments were the times a species was observed alone, or with one or two other additional species (species 1, species 1-species 2, species 1-species 3, species 1-species 2species 3). To evaluate the patterns of species association under sheltered positions during every observation in the sympatric experiment, the number and species of individuals located in each shelter was noted. Thus, it was possible to compare how many times a species used a refuge with conspecifics or with one or two of the other species.

To test for intraspecific interactions we compared the mean number of times one or two individuals of the same spccies occupied the same sheltered position with a t-test.

In experiments i) and ii) each compartment of the aquarium was considered as a replicate.

iii) With this experiment we tried to determine the spccies associations established after a period of time, and thus we let the fish disperse freely between compartments. If a species had preferences to coexist or, on the contrary, to avoid other species, the final distribution of individuals should tend to be sympatric or allopatric, respectively. Communication between compartments was through two openings at the top of each partition, which allowed the fishes to swim freely from compartment to compartment. Sand $(<1 \mathrm{~mm})$ was used as the substratum.

At the beginning of the study 28 bullhead $(38.6 \pm 2.3 \mathrm{~mm}$, mean total length $\pm 1 \mathrm{SE}), 4$ gudgeon $(77.6 \pm 4.9 \mathrm{~mm})$, and 61 stone loach $(46.1 \pm 1.9 \mathrm{~mm})$, were added to the first compartment. These densities of fish were inside the maximum range observed under natural conditions (MANN, 1971; PRENDA, unpubl. data).

Fish were observed just after they were added to the aquarium $(\mathrm{t}=0)$, and on five further occasions throughout a period of $30 \mathrm{~h}(\mathrm{t}=3,4.75,21.5,24.9,29 \mathrm{~h})$. The number of individuals of each species per compartment were noted as in the previous experiment.

All variables used in parametric analysis were logtransformed.

\section{RESULTS}

\section{Substratum preferences}

Stone loach, gudgeon and bullhead strongly selected the sheltered subskate (Table II) (Fig. 1). This preference was stronger (Table II, $\mathrm{P}<0.0001$ in all cases) when the three species were together (Fig. Ib). Stone loach in both cases displayed a clear tendency to stay in sheltered positions (Table II, Tukey range test, $\mathrm{P}<0.05$ ). Bullhead and gudgeon showed a higher tendency to use the other substrata when alone. After sheltered positions, bullhead significantly preferred gravel (Table II, Tukey range test, $\mathrm{P}<0.05$ ), while gudgeon, secondly, selected sandy substratum (Table II, Tukey range test, $\mathrm{P}<0.05$ ) (Fig, la).

\section{Species associations under sheltered positions}

No species showed any preference for any specific species combination (Fig. 2). There were no significant differences between the mean relative frequency of all possible species combinations found under shelter for each species (comparison of the mean number of times each species combination was obscrved, one-way ANOVA, P>0.38, in all cases). Apparently each species used the sheltered positions at random, independently of the presence/absence of any other species. Notwithstanding, bullhead and gudgeon seemed to prefer to stay alone and in addition, showed a certain reluctance to

TABLE II. Significance the frequency of substrata use for the allopatric and sympatric trials (see Fig. I) tested with one-way ANOVA. The numbers in brackets are homogeneous groups (1: sand + shelter, 2: gravel, 3: sand). $\mathrm{n}=9$. $* \mathrm{P}<0.05, * * \mathrm{P}<0.01, * * * \mathrm{P}<0.001$.

TABLA 11. Kesumen del ANOVA de la frecuencia de uso de los tres upos de substrato para los experimentos en que cada especie estuvo en alopatría o en simpatría (ver la Fig. 1). Los paréntesis encierran grupos homogeneos (1: arena+refugio, 2: grava, 3: arena). $\mathrm{n}=9$. $* \mathrm{P}<0.05, * * \mathrm{P}<0.01, * * * \mathrm{P}<0.001$.

\begin{tabular}{lcc}
\hline \multicolumn{1}{c}{ trial/species } & $F$ & $\begin{array}{c}\text { Homogeneous groups } \\
\text { (Tukey multiple range test) }\end{array}$ \\
\hline a) Allopatric & & $3,2,1$ \\
bullhead & $8.6^{*}$ & $(3,2), 1$ \\
stone loach & $175^{* *}$ & $2,(3,1)$ \\
gudgeon & $27.8^{* * *}$ & \\
b) Sympatric & & $(3,2), 1$ \\
bullhead & $27.1^{* * *}$ & $(3,2), 1$ \\
stone loach & $76.7^{* * *}$ & $(3,2), 1$ \\
gudgeon & $999.9^{* * *}$ & \\
\hline
\end{tabular}




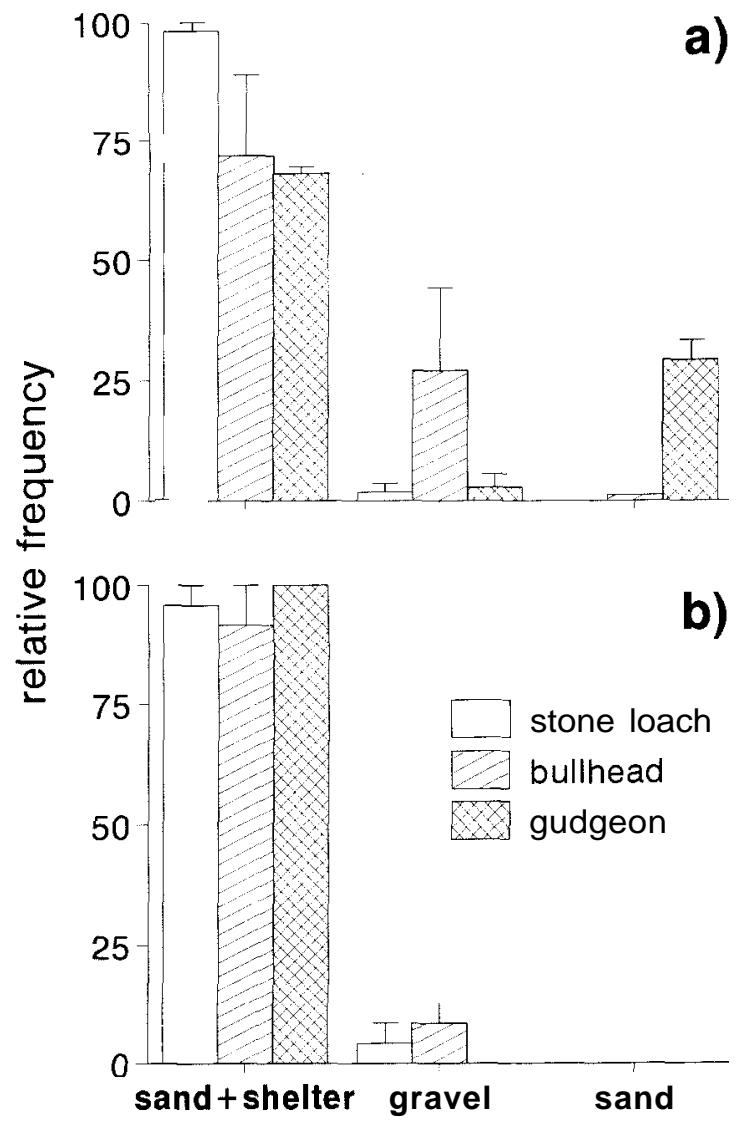

FIGURE 1. Mean relative frequency of the three kinds of substrata use by a) single species (allopatrically) and b) mixed species group (sympatrically). Error bars: \pm 1 SE.

FIGURA 1. Frecuencia media de uso de cada uno de los tres tipos de substrato por a) cada especie en solitario (en alopatría) y b) las tres especies juntas (simpatría). Barras de error: \pm 1 ES.

occupy the same sheltered patch simultaneously with the two remaining species (Fig. 2).

The three species clearly preferred to stay alone shelter (ttest, $\mathrm{P}<0.0001$ in all cases) (Fig. 3) rather than to share it with a conspecific. But as with the previous test, bullhead followed by gudgeon displayed a stronger tendency to be found alone than stone loach. The intraspecific exclusion in the three species was statistically much more important than the interspecific one (see Figs. 2 and 3).

\section{Species associations after dispersal}

Dispersal patterns differed between species. After approximately $21 \mathrm{~h}$, the three species established their

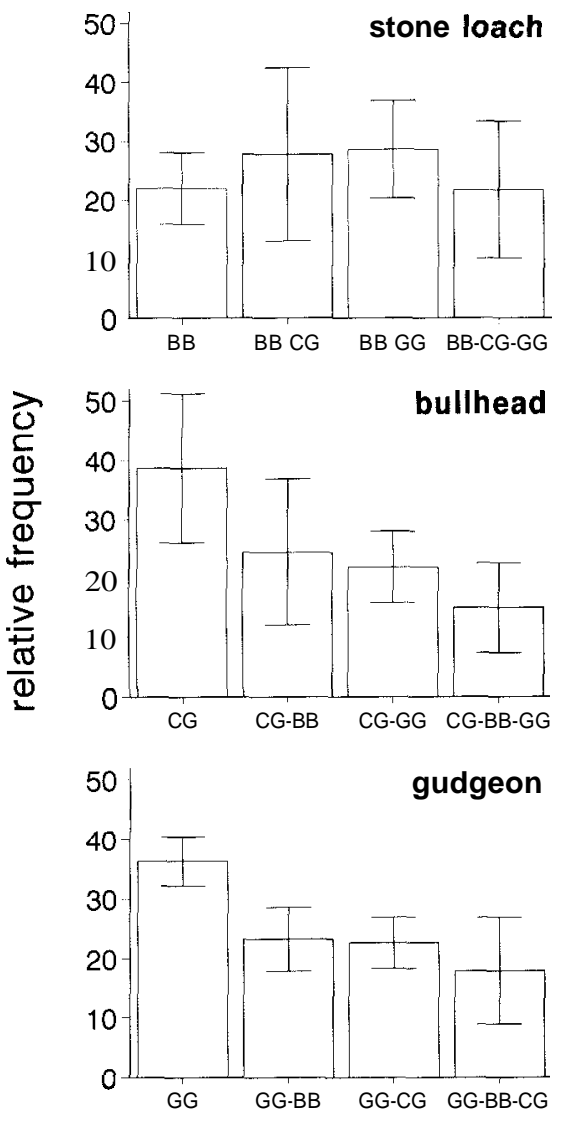

FIGURE 2. Mean relative frequency of species combinations under sheltered positions. Error bars: + SE. BB: B. barbatula, CG: C. gobio, CG: G. gobio.

FIGURA 2. Frecuencia relativa media de las distintas combinaciones de especies observadas compartiendo un mismo refugio. Barras de error: \pm 1 ES. BB: B. barbatula, CG: C. gobio, CG: G. gobio.

distribution between compartments. The final distribution reached by stone loach did not differ from an homogeneous distribution in which the three compartments were used by the same number of individuals ( $\chi^{2}$ analysis, $P=0.59 ; 2$ d.f.). Bullhead and gudgeon, on the contrary, displayed a contagious distribution, bullhead selecting equally the compartments 1 and 3 and gudgeon preferring compartment 3 (Fig. 4). In the final distribution reached by the three species, there was no evidence of any species association (Spearman Rank correlation test, $0.17<r>0.28, P>0.29$ in all cases, $n=3$ ). However, to test for the potential influence of sample size on the final distribution pattern observed, we regressed the number of individuals with the coefficient of variation of the relative frequencies of the three compartments per species. The 

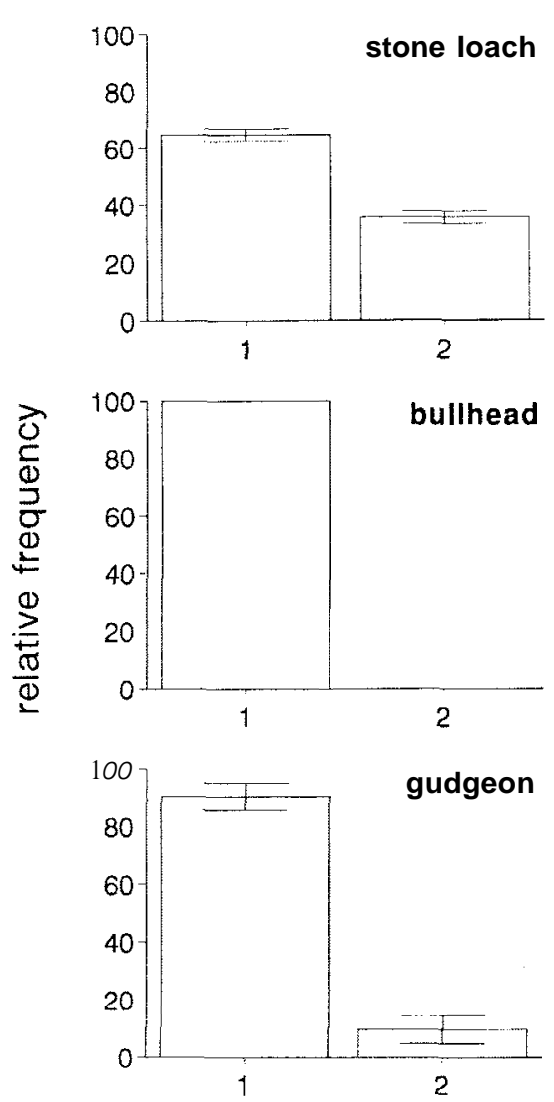

FIGURE 3. Mean relative frequency of one or two individuals per species under sheltered positions. Error bars: \pm I SE.

FIGURA 3. Frecuencia relativa media a la que se han observado uno o dos individuos de la misma especie en un mismo refugio. Barras de error: \pm 1 ES.

variability in the distribution significantly diminished with sample size $\left(\mathrm{F}_{2}=11792.4, \mathrm{R}^{2}=99.9 \%, \mathrm{P}=0.006\right)$. Thus, the result obtained may be a consequence of both the sample size and the different interacting capacity of each species.

\section{DISCUSSION}

The results of this study do not present evidence of interspecific interaction between bullhead, stone loach and gudgeon. Previous observations both in the field and in the laboratory reached a similar conclusion (WELTON et al., 1983, 1991; PRENDA et al., 1997). However, it does not mean that under natural conditions the three species tend to coexist in the same habitat patch. In a field study of fish microhabitat preferences, stone loach, gudgeon and bullhead could be assigned to different habitat guilds (PRENDA et al. ,1997).
Stone loach preferred shallow depositional areas and both bullhead and gudgeon were habitat generalists, although they did not share the same patches. In these species, according to PRENDA et al. (1997), this habitat partitioning observed in the field could be a mechanism to avoid exploitative competition.

It seems that bullhead are stronger interactors than gudgeon and stone loach. The latter species. on the contrary, tends to be more social than the other two. Various social advantages of living in shoals have been demonstrated for stone loach (STREET \& HART, 1985). This is a non-visual feeder, mostly inactive during the day, that lies concealed under stones, often in groups of several individuals (SMYLY, 1955). Stone loach was able to locate a concealed food source more rapidly when group size increased (STREET \& HART, 1985). According to SMYLY (1957) bullhead are always solitary and do not share the stones where they live, with conspecifics or with stone

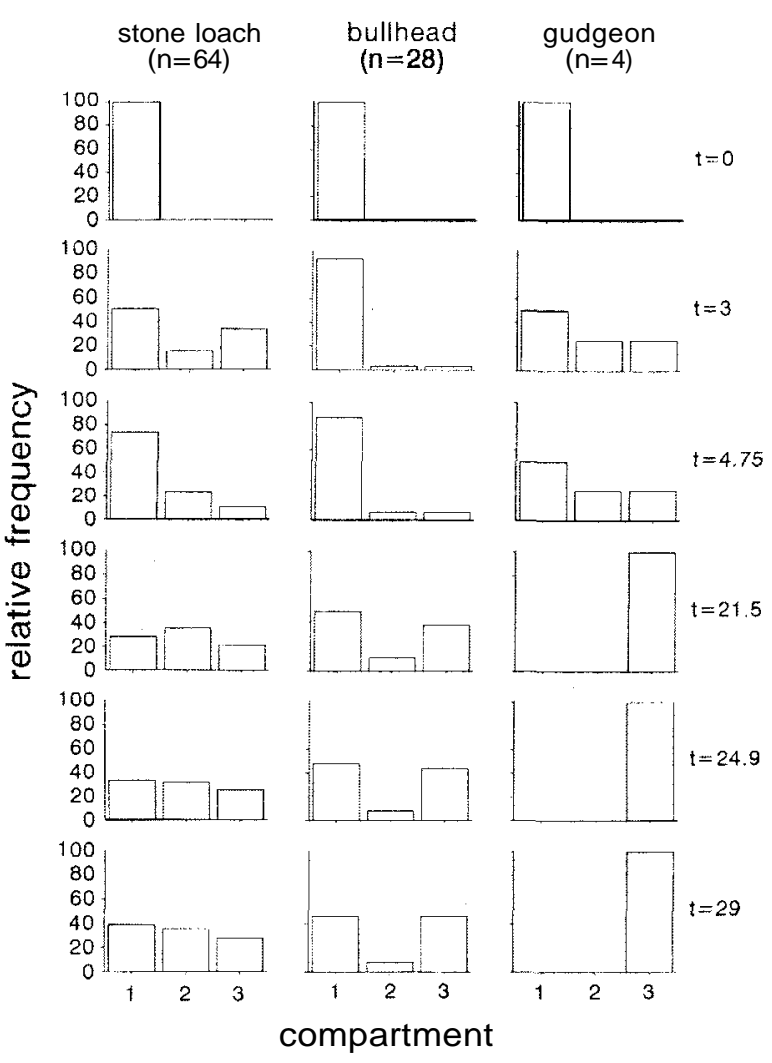

FIGURE 4. Relative frequency of compartment use by stone loach, bulhead and gudgeon throughout time (t: hours) (See Materials and Methods).

FIGURA 4. Variaciones en la frecuencia relativa de uso de distintos compartimentos por el lobo de río, el cavilat y el gobio a lo largo del trempo (t: horas) (Ver Material y Metodos). 
loach. Other species, such as trout fry (Salmo trutta) were driven from their preferred habitats by bullhead (GAUDIN \& CAILLERE, 1990). The gudgeon is a small generalist cyprinid (MANN, 1980; MANN et al., 1984; LOBÓN-CERVIÁ et al.. 1991; ZWEIMULLER, 1995) that is not as territorial as bullhead nor as social as stone loach. In a chalk stream in southern England gudgeon usually coexisted with more than four species in the same microhabitat patch, as did stone loach, while bullhead was found mostly with three or less fish species (PRENDA et al., 1997).

The fish distribution between compartments was dependent on fish species, although sample size was very different for each species and was strongly correlated with the final pattern of distribution observed. As the initial density increased so did the homogeneity of distribution between compartments. The results obtained from the previous experiments might suggest that stone loach distribution should be the least

homogeneous, due to their social behaviour, and bullhead should be just the opposite, because of their territoriality. In this way, bullhead potential interaction may have been minimised. However, the high density of individuals used in this experiment may have precluded such responses. No species segregation indicative of negative interactions, was detected.

When a choice of three different substrata (sand, gravel and sand with shelter) was offered to the fish, the three species clearly selected shelter, especially when the three were together, and in sympatric conditions were indifferent to the remaining substrata. Shelter is a key factor in fish distribution (IBBOTSON et al., 1994). Bullhead and stone loach usually inhabit sites with high instream cover provided by weed or large stones (WELTON et al.,1983). Gudgeon, however, prefer more open positions (PRENDA et al., 1997). In the allopatric trial the result was very similar although bullhead and gudgeon showed secondary preferences for gravel and sand, respectively. This result may be a consequence of intraspecific competition. Density increases in bullhead and gudgeon lead to a few individuals using apparently suboptimal habitats possibly having been driven out of the preferred patch. In this case, the substratum that ranked second for bullhead and gudgeon coincided, in general, with the preferences observed previously (MANN, 1980; WELTON et al., 1983; ZWEIMULLER, 1995; PRENDA et al., 1997). Notwithstanding, substratum preferences reported for these species arc not consistent (Table III) This (1991). (1991) suggests that with the exception of bullhead, which needs large stones with undercavities to nest, substratum is not of great importance for these species. At least, not as important as shelter.

These results suggest that the intraspecific exclusion in the species examined was more important than the interspecific one. FREEMAN \& GROSSMAN (1992) found that interspecific interactions were rare, whereas intraspecific competition was sometimes more intense in some American cyprinids. The interspecific interactions were presumably soft interference competition that produced the very limited nonstatistically significant-segregation between species. However, the intraspecific interactions were responsible for the changes in substratum preferences and shelter use. Under natural conditions the competition between individuals using the same

TABLE III Summary of stone loach, bullhead and gudgeon substrata preferences, according to different authors. (1) SMYLY (1955), (2) ZWEIMÜLLER (1955), (3) WELTON et al. (1983). (4) MANN et al. (1984), (5) PRENDA et al. (1997), (6)WELTON et al. (1991), (7) SMYLY (1957), (8) GAUDIN \& CAILLERE (1990), (9) MANN (1980), (10) LOBÓN CERVIÁ et al.

TABLA III. Resumen de las preferencias de substrato del lobo de rio, cavilat y gobio según diferentes autores. (1) SMYLY (1955), (2) ZWEIMÜLLER (1955), (3) WELTON et al. (1983), (4) MANN et al. (1984), (5) PRENDA et al. (1997), (6) WELTON et al. (1991), (7) SMYLY (1957). (8) GAUDIN \& CAILLERE (1990), (9) MANN (1980), (10) LOBÓN CERVIÁ $r t$ al.

\begin{tabular}{|c|c|c|}
\hline species & substrata preferences & References \\
\hline \multirow[t]{5}{*}{ stone loach } & Sand, gravel, mud. & (1) \\
\hline & $\begin{array}{l}\text { Shallow and current cxposed location without clear affinities } \\
\text { for a particular substratum. }\end{array}$ & (2) \\
\hline & Macrophyte areas with a substratum of silt. & (3) \\
\hline & Stone or gravel, do not reject mud and sand & (4) \\
\hline & Depositional areas & (5) \\
\hline \multirow[t]{5}{*}{ bullhcad } & Gravel. & (6) \\
\hline & $\begin{array}{l}\text { Under stone and nearly always on a bottom of firm sand or } \\
\text { gravel, rarely on hard rock or mud. }\end{array}$ & (7) \\
\hline & Stone or gravel, rarely on areas of sand or mud & (4) \\
\hline & Shaded zones which lacked emergent vegetation. & (8) \\
\hline & Large gravel flints or weed & (3) \\
\hline \multirow[t]{4}{*}{ gudgeon } & Do not have a strong dependence on the substratum & $(5)$ \\
\hline & Sand or gravel, rarely on mud. & (9) \\
\hline & Pebbles and stones & $(10)$ \\
\hline & Avoid gravel sediments, preferences for sand & (2) \\
\hline
\end{tabular}


resources may be stronger than between individuals that display larger differences in resource use.

\section{ACKNOWLEDGEMENTS}

We thank Alan Grayston for his help with the controlled experiments and S. Clough and an anonymous referee for their

\section{REFERENCES}

FREEMAN, M.C. \& G.D. GROSSMAN, 1992. A field test for competitive interactions among foraging stream fishes. Copeia, 1992: 898-902.

GAUDIN, P. \& L. CAILLERE, 1990. Microdistribution of Cottus gobio L. and fry of Salmo trutta L. in a first order stream. Pol. Arch. Hydrobiol., 37: 81-93.

GREENBERG, L. A. 1988. Interactive segregation between the stream fishes Etheostoma simoterum and $E$. rufilineatum. Oikos, 51: 193-202.

IBBOTSON, A., P.D. ARMitAGE, W. BEAUMONT, M. LANDLE \& S. WELTON, 1994. Spatial and temporal distribution of fish in a small lowland stream. Fish. Manag. Ecol., 1: 143-156.

LOBÓN-CERVIÁ, J., C. MONTANES \& A. DE SOSTOA, 1991. Influence of environment upon the life history of gudgeon, Gobio gobio (L.): a recent and successful colonizer of the Iberian Peninsula. J.Fish Biol., 39: 285-300.

MANN, R.H.K. 1971. The populations, growth and production of fish in four small streams in southern England. J. Anim. Ecol., 40: 155-190.

MANN, R.H.K. 1980. The growth and reproductive strategy of the gudgeon, Gobio gobio (L.), in two hard-water rivers in southern England. J. Fish Biol., 17: 163-176.

MANN, R.H.K. 1989. Fish population dynamics in the river Frome, Dorset. Reg. Rivers, Res. Manag., 4: 165-177. useful comments and suggestions to an earlier version of the manuscript. This research was supported by a Fleming Grant from the Spanish Ministry of Education and Science and The British Council to the first author.

MANN, R.H.K., C.A. MILLS \& D.T. CRISP, 1984 Geographical Variation in the Life History Tactics of Some Species of Freshwater Fish. In: Fish Reproduction. Strategies and Tactics. (POTTS, G. W. \& R. J WOOTTON, eds.), 171-186. London: Academic Press.

PRENDA, J., P. D. ARMITAGE \& A. GRAYSTON, 1997. Habitat use by the fish assemblages of two chalk streams. $J$. Fish Biol., 51: 64-79.

SMYLY, W. J. P. 1955. On the biology of the stone loach Nernacheilus barbatula (L.). J. Anim. Ecol., 24: 167-186.

SMYLY, W. J. P. 1957. The life-history of the bullhead or Miller's thumb (Cottus gobio L.). Proc. Zool. Soc. London, 128: 431-453.

STREET, N.E. \& J.B. HART, 1985. Group size and patch location by the stone loach, Noemacheilus barbatula, a nonvisually foraging predator. J. Fish Biol., 27:785-792.

WELTON, J.S., C.A. MILLS \& E. L. RENDLE, 1983. Food and habitat partitioning in two small benthic fishes, Noemacheilus barbatula (L.) and Cottus gobio L. Arch Hydrobiol., 97: 434-454.

WELTON, J.S., C.A. MILLS \& J.R. PYGOTT, 1991. The effect of interaction betweenn the stone loach Noemacheilus barbatula (L.) and the bullhead Cottus gobio (L.) on prey and habitat selection. Hydrobiol., 200: 1-7.

ZWEIMULLER, I. 1995. Microhabitat use by two small benthic stream fish in a 2nd order stream. Hydrobiol., 303: 125-137. 